\title{
Aortoesophageal aneurysmal sac and aorto-left pleural fistula - a rare complication of aortic aneurysm
}

\author{
Przetoka między workiem tętniaka a przełykiem i lewą opłucną \\ — niecodzienne powikłanie tętniaka aorty
}

\author{
Ewa Korościk ${ }^{1}$, Marta Kałużna-Oleksy ${ }^{1}$, Magdalena Dudek ${ }^{1}$, Sebastian Stefaniak², \\ Ewa Straburzyńska-Migaj ${ }^{1}$ \\ $11^{\text {st }}$ Department of Cardiology, University of Medical Sciences, Poznan, Poland \\ ${ }^{2}$ Department of Cardiac Surgery and Transplantology, University of Medical Sciences, Poznan, Poland
}

\begin{abstract}
A 62-year-old female with history of descending aortic aneurysm after stentgraft implantation four years ago was diagnosed with endoleak within the aneurysmal sac (Fig. 1A). The new stentgraft ZENITH 2D 38-186 (femoral approach) was implanted. The reason for admission was paroxysmal atrial fibrillation (AF) and left pleural effusion. At the time of admission, the patient presented with severe dyspnoea, cough, haematemesis, nausea, dysphagia, and stabbing chest pain radiating to the left shoulder. The clinical state was severe but stable. In physical examination pain during palpation along the left edge of the sternum and in ribs III-IV were observed, auscultation revealed increased bronchial murmur in the upper part and muted blistering noise in lower part of the left lung. The blood pressure was $90 / 60 \mathrm{~mm} \mathrm{Hg}$, and the heart rate was $85 \mathrm{bpm}$ (AF in ECG). Laboratory tests showed elevated levels of procalcitonin $(0.52 \mathrm{ng} / \mathrm{mL})$ and D-dimer $(2893 \mathrm{ng} / \mathrm{mL})$ with leucocytosis and very high level of C-reactive protein (CRP) (increasing during hospitalisation $322.4-447.7-453.0 \mathrm{mg} / \mathrm{L}$ ) and alkalosis. Chest X-rays showed haemopneumothorax. Initially the new implanted stentgraft was patent (Fig. 1B, C). Computed tomography showed pneumomediastinum, and haemopneumothorax left (Fig. 1D, E; 2A), and contrast leakage into the left pleura and mediastinal cavities (Fig. 1F; 2B). Antibiotic treatment was immediately initiated (empiric cefazolin IV without effect, changed to ciprofloxacin + metronidazole IV) obtaining lower levels of CRP and procalcitonin. With suspicion of mediastinitis the patient was handed over to the thoracic surgery department for surgical treatment. This case presents a very rare complication of aortic aneurysm like aortoesophageal aneurysmal sac and aorto-pleural fistula. Contact with mediastinum usually results in mediastinitis. Diagnosis of those complications is very difficult, resulting in a high rate of mortality.
\end{abstract}
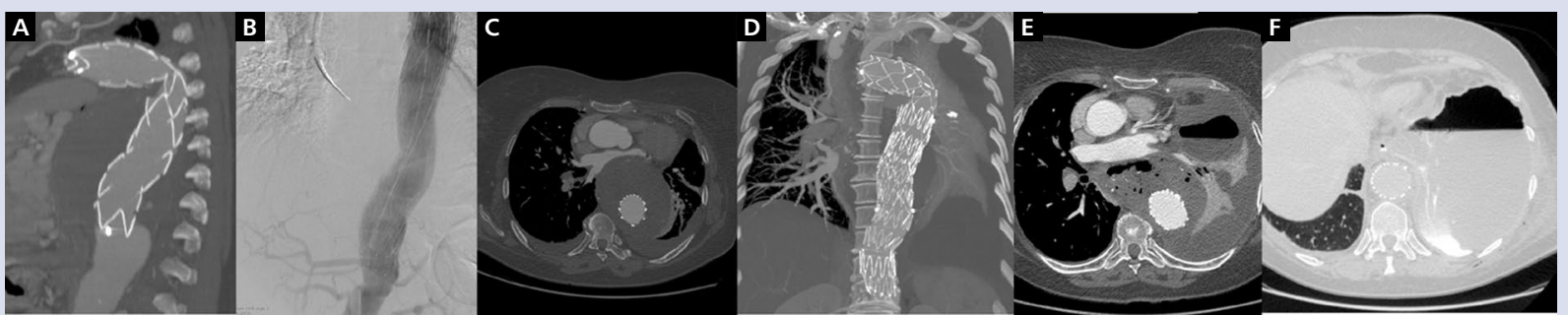

Figure 1. A. Computed tomography (CT) revealed an endoleak in a distal part of the previous stentgraft. First post-operative images after new stentgraft implantation: digital subtraction angiography (B) and CT (C) showed patent stentgraft; D, E. Next CT taken because of worsening of clinical state with haematemesis revealed pneumomediastinum, haemopneumothorax left; F. CT oesophagography showed contrast leakage into mediastinum and left pleura

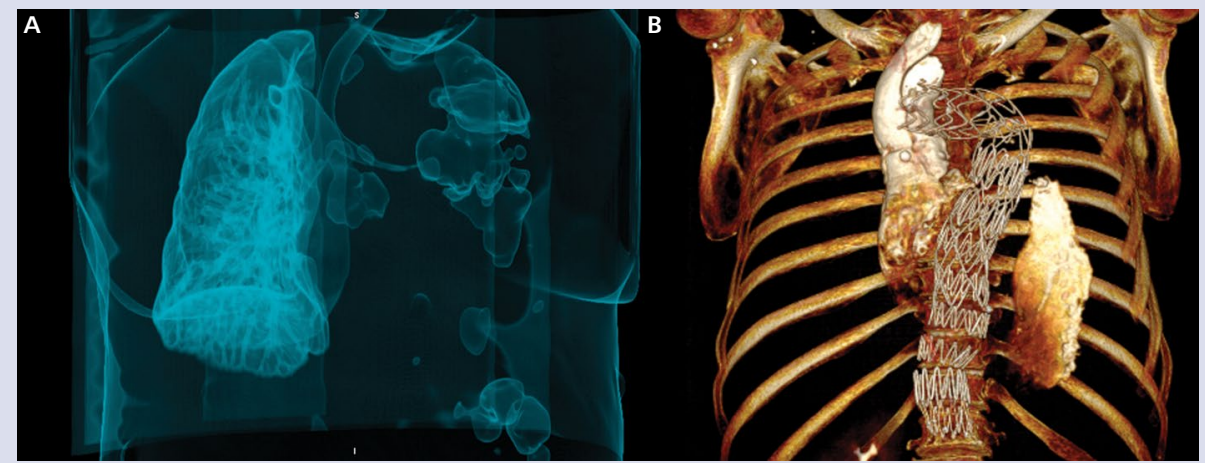

Figure 2. A. Computed tomography (CT) volume-rendering technique image of airways showed free air in left pleura and total compression of left lung; B. CT volume-rendering technique image of oesophagus with contrast leakage into the left pleura

Address for correspondence:

Ewa Korościk, MD, 1 1t Department of Cardiology, Medical University, ul. Długa 1/2, 61-848 Poznań, Poland, e-mail: ewakoroscik@wp.pl

Conflict of interest: none declared

Kardiologia Polska Copyright @ Polskie Towarzystwo Kardiologiczne 2017 